\title{
Factors Influencing Intention to Use Web 2.0 in Indonesian Vocational High Schools
}

\author{
https://doi.org/10.3991/ijet.v15i05.10605 \\ Lantip Diat Prasojo \\ Universitas Negeri Yogyakarta, Yogyakarta, Indonesia
}

\author{
Akhmad Habibi $\left.{ }^{(}\right)$, Amirul Mukminin, Sofyan, Boy Indrayana, Kaspul Anwar \\ Universitas Jambi, Jambi, Indonesia \\ Akhmad.habibi@unja.ac.id
}

\begin{abstract}
E-learning based on Web 2.0 technology is widely available for education to support teaching and learning efficiency and effectiveness. The main objective of this research is to examine factors influencing teachers' Intention to Use Web 2.0 (IUW) into teaching in Indonesian Vocational High Schools (VHSs) using Technology Acceptance Model (TAM) and Technological Pedagogical Content Knowledge (TPACK) frameworks. Based on these two frameworks, we developed a survey instrument from previous related studies. The instrument was piloted; it was examined through factor analyses and Cronbach's alpha for the reliability. For the main data collection, this study involved 640 participants who completed 31 online items of seven validated variables. For data analysis, we applied Analysis of Variance and t-test, and Confirmatory Factor Analysis (CFA). To assess the model, a Covariance-Based Structural Equation Modeling (CB-SEM) was used. Results informed that there was a significant difference based on gender regarding IUW; however, no significant differences were informed based on age and subject area. The findings also informed that TPACK, Subjective Norm (SN), and Facilitating Condition (FC) significantly influenced IUW.
\end{abstract}

Keywords-TAM, TPACK, Web 2.0, Structural equation modeling

\section{Introduction}

Recently, the development and implementation of Information and Communication Technology (ICT) in education is unavoidable. ICT is defined as all terms including all electronic devices used to obtain, record, store, share, and exchange information [1]. The use of ICT including Web 2.0 is believed to enhance the proses of teaching and learning in all types of schools [2] including Vocational High Schools (VHSs).

Web 2.0 has been a global impact on people to communicate [3]. It is defined as the next generation of the World Wide Web in which it presents a more interactive and dynamic web experience from static HyperText Markup Language (HTML). The focus of Web 2.0 is on collaboration and sharing functions via social networking ser- 
vices. Social networking services applications e.g. Wikis, Blogs, Social Media, Content Hosting Services, and Podcasting are now becoming important technologies in enhancing learning [4]. Essentially, these kinds of technologies provide more flexible learning strategies and approaches within the workplace or anyplace through the Internet [5].

With the rapid penetration and use of Web 2.0, many teachers welcome its use in teaching and learning [6]. The trend emerges in not only developed countries but also developing countries. Indonesia as one of the developing countries has more than 147 million internet users that seem potential for research and practices of Web 2.0 in education. All educational levels including VHSs should be included as they are integral part in Indonesian education.

Many researchers have discussed the use of Web 2.0 within the context of Indonesia e.g. in Politics [7]; in Health [8]; in Governance [9]; in Economics [10]. However, few studies have explored its use in the context of Indonesian education [11]. Even fewer studies were conducted in vocational education. Therefore, this study focused on the use of Web 2.0 in Indonesian VHSs. In particular, this study aims at examining factors influencing Intention to Use Web 2.0 (IUW). It was conducted to explore the VHSs teachers' IUW in their teaching activity through Covariance-Based Structural Equation Modeling (CB-SEM), the most common approach to SEM, namely for distribution assumptions, sample size, and theory testing.

\section{$2 \quad$ Literature Review}

Web 2.0 can transform educational stakeholders into active users of technology used for knowledge and information sharing [4, 5]. The use of Web 2.0 tools into education can produce a good environment and support innovative teaching and learning variation. It is linked to the concepts of practical communities, practice, content syndication, creative activity for learning, peer-to-peer learning, and personal learning environment creation for formal and informal education [12].

\subsection{Technology Acceptance Model (TAM)}

Originating from the Theory of Reasoned Action (TRA) [13], technology acceptance research has its momentum for the popularity in $1980[14,15]$. Technology acceptance is considered as willingness of users to apply technology for activities that can be supported by its use [16]. By the increasing of technology availability and innovation, many studies have informed that the perceptions and beliefs of technology users should be understood as an emergent key for the success of ICT integration [17]. Users' beliefs on influencing factors for intention to use technology are the basic root for technology acceptance studies affecting the actual integration of technology [18, 2]. Prior technology acceptance studies have reported the intention to use as a strong predictor of actual behavior [19, 2, 15].

Technology Acceptance Model (TAM), a theory modeling of how users accept and use technology, is considered as one of the most well-known model for technology 
acceptance prediction with a robust framework [20]. TAM was constructed by [14] who adapted the TRA [13]. The TRA postulates that beliefs influence attitude leading to intention, and then guiding to behavior. This belief-attitude-intention-behavior relationship to the acceptance of new technology was included in TAM. In this framework, [14] Perceived Usefulness (PU) and Perceived Ease of Use (PEU) are salient predictors of the intention to use technology. TAM recommends that when people use a new technology for an activity, PU and PEU will influence their decision, accepting or rejecting it. PU is defined as the degree to which an individual believes that a particular technology could improve his or her job performance while PEU is defined as the degree to which a user believes that a certain technology could be free of mental effort [14]. PU and PEU are influenced by external variables, namely system characteristics, participation design, and implementation process [21]. Many studies have adapted TAM in explaining the use of technology in teaching and learning process $[22,23,24,25]$. From its first development, TAM has been examined and extended in many research areas. However, few studies were conducted in a vocational education context.

\section{$2.2 \quad$ TPACK}

If the application of TAM is done in educational research, some specific variables are recommended to be in consideration as extended factors [26]. For this suggestion, the importance of increasing TAM modification should be taken into account [27]. Therefore, we included TPACK as an extended framework for this study.

TPACK framework was established [28] based on [29] pedagogical content knowledge model aiming to understand the way teachers' acquiring knowledge for technology integration. TPACK framework could be a guiding framework for exploring teachers' knowledge acquisition for technology integration [30]. However, most studies on the TPACK have mainly informing TPACK's measurement validity $[31,32,33]$ and its merit to scaffold teachers' structure of knowledge [33,30]. Little research was conducted in a way to promote technology integration during teaching, especially in Indonesian VHSs. Therefore, we included it linked to teachers' use of technology in VHSs' teaching and learning processes. Specifically, it aims to verify the contribution of TAM and TPACK to VHS teachers' acceptance of technology integration and to report evidence for further research of Web 2.0.

\subsection{Variables}

PU has been informed to be useful in teaching, namely fostering students' achievement, improving information and knowledge sharing, providing good facilitates for learning, and improving teachers' productivity and creativity [34,35].

Many studies informed about the role of PEU in technology integration [36, 37]. If technology was perceived to be easy to use, the PU would improve and produce wider intention to use technology [17, 38, 39].

Perceived Enjoyment (PE) has been previously linked with a behavioral intention [40. 41, 42]. It was also related to the PEU [2]. Users' experience, involvement, and 
social activity supported by technologies sometimes trigger fun and satisfactory feeling, as well as other favorable feelings among people [1].

Self-efficacy is linked to a belief in someone's ability that is confirmed to influence people behavior [43]. There was a positive prediction of technological self-efficacy such as computer, Internet, and digital technology as well as Web 2.0 upon intention to use [12].

Subjective norm ( $\mathrm{SN})$ is considered as the way people from a collectivist-history background are more likely to conform to group expectations [44]. SN [37] was informed to have direct effects on intention to use technology.

Facilitating Condition (FC) could be supported by addressing appropriate infrastructure, professional improvement, technical support, and policies supporting technology integration in education [45].

TPACK in this study is knowledge about ways to address the combination of different areas in teaching and to apply appropriate pedagogical approaches for certain contents with appropriate technologies $[33,30]$.

\subsection{Research questions and hypothesis}

Even though many empirical studies used either TAM or TPACK to examine technology integration in education, it is suggested that extra efforts are still required to validate available research findings. Particularly, studies involve different technologies, organizational contexts, and users [46]. Therefore, this study stems from a call for more empirical validation of an academic model in different settings. Specifically, this study aimed at examining factors influencing teachers' IUW in their teaching activity in Indonesian VHSs. To create a clear direction of the study, we established two research questions: RQ1. Are there any significant differences between VHS teachers' gender, age, and subject area regarding their IUW into teaching? RQ2. To what extent do the independent variables predict the dependent variable? In accordance with the second research question, we proposed seven hypotheses (Fig. 1):

H1: PU will be significant in predicting IUW.

H2: PEU will be significant in predicting IUW.2.0

H3: PE will be significant in predicting on PU

H4: WSE will be significant in predicting IUW

H5: SN will be significant in predicting IUW.

H6: FC will be significant in predicting IUW.

H7: TPACK will be significant in predicting IUW. 


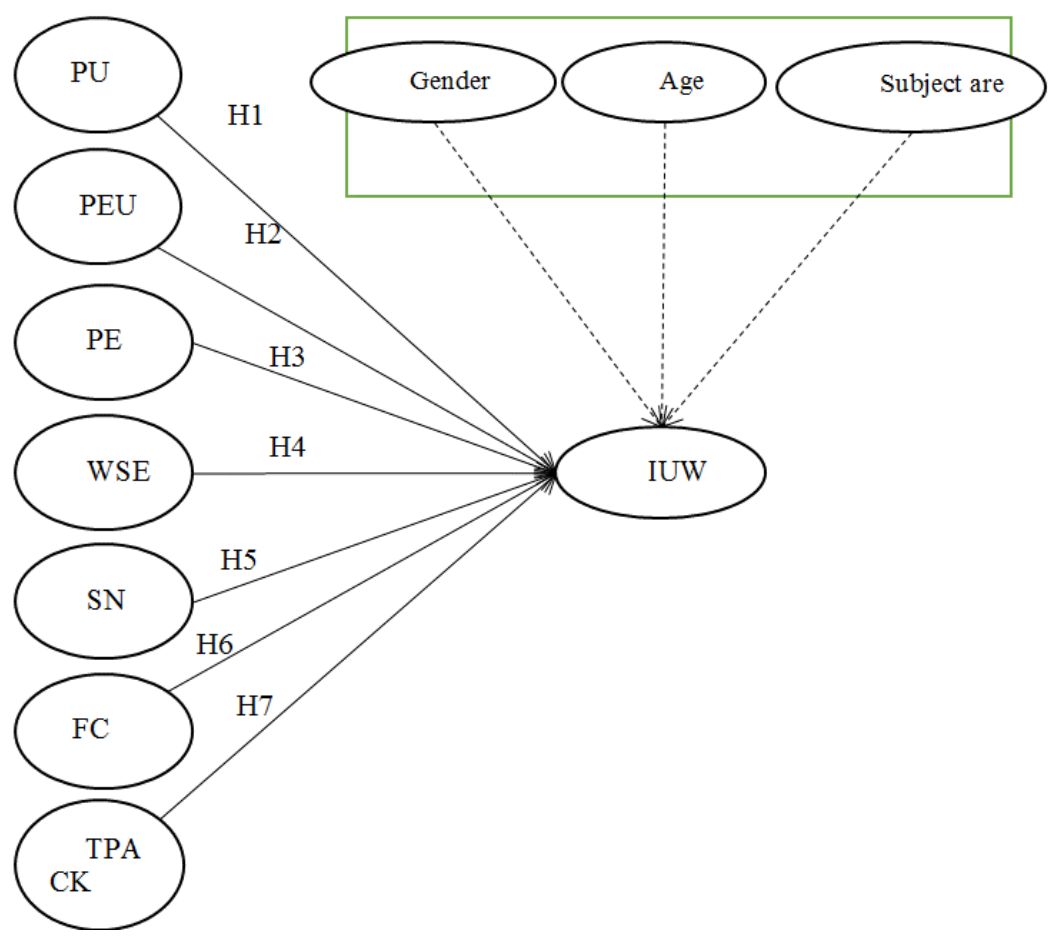

Fig. 1. Proposed model

\section{$3 \quad$ Method}

We used a survey as a non-experimental study that has been popular among social science researchers for this study. The target population of this research is Indonesian VHSs teachers who integrate Web 2.0 in their teaching. The population of this research was all Indonesian VHSs teachers. Prior to the main study data elaboration, the development of the survey instrument was done; the validation process in this phase involved discussions with experts in educational technology. Afterward, we piloted the instrument and used Exploratory Factorial Analyses (EFA) and Cronbach alpha to examine the reliability. Analysis of Variance (ANOVA) and t-test were also used to examine the difference among demographic information regarding IUW in Indonesian VHS. We used CB-SEM to determine factors influencing IUW.

\subsection{Instrumentation}

The survey instrument employed in this study comprised of items adapted from previous studies [5. 12, 47, 48, 49, 50, 51, 52, 53]. Forty-two items were included in the adaptation stage. The instrument was reviewed by a panel of five educational technology experts for its socio-cultural aspect. Seven items were dropped due to redundant phrases and contextualized statements regarding Indonesian education. After 
the process, the instrument (35 items) was translated to Indonesian (Table 1). A 5point Likert scale from 1 (strongly disagree) to 5 (strongly agree) was attributed in the instrument. Within the instrument, we included demographic information; gender, age, and teaching experience.

\subsection{Pilot study validation of the instruments}

The instrument was pilot-tested to 186 Indonesian VHSs' teachers. We randomly distributed printed materials to the participants in 20 VHSs. Before the distribution, we submitted an official permission letter to ministry of education which was approved by the head of vocational education affair. Cronbach's alpha was measured for the reliability of the scales. The internal consistency of the scales varied from .765 to 934. The reliability and validity of the pilot study are informed in Table 1. One of the constructs, PE with 4 items, was dropped due to its low Cronbach's alpha value $(\alpha<$ .700). Therefore, 31 items remained and were included for further analysis.

The analysis of the pilot study data was also done through EFA to establish the validity of the instrument. Kaiser-Meyer-Olkin (KMO) of sampling adequacy and Bartlett's test of sphericity were computed. The index of KMO of this study was .873 considered as "meritorious" as Kaiser's index informed [54]. The $x^{2}$ value of Bartlett's sphericity test was $5834.604(\mathrm{p}<.01, \mathrm{df}=4651)$ yielding suitable assessment for the factor analysis [54]. A Principal Component Analysis (PCA) was also conducted. Regarding the factor loadings, a .500 factor load in the EFA was taken into account for the data analysis. No items were dropped from the scale in the EFA process. With eigenvalue above 1, the EFA achieved a seven-factor model; PU, PEU, WSE, SN, FC, TPACK, and IUW. Table 1 performs the number of items, eigenvalue, mean, and Cronbach's alpha of the instrument.

Table 1. Descriptive statistics and alpha of the pilot study (n. 186)

\begin{tabular}{|c|l|c|c|c|c|c|c|}
\hline \multirow{2}{*}{ No } & \multirow{2}{*}{ Component } & Number of item & \multicolumn{3}{|c|}{ Eigenvalues } & Mean & $\boldsymbol{\alpha}$ \\
\cline { 3 - 8 } & $\mathbf{3 1}$ & Total & $\begin{array}{c}\text { \% of Vari- } \\
\text { ance }\end{array}$ & Cumulative $\%$ & & \\
\hline 1 & PU & 4 & 1.351 & 4.503 & 73.409 & 3.50 & .765 \\
\hline 2 & PEU & 4 & 1.493 & 4.976 & 68.906 & 3.92 & .828 \\
\hline 3 & WSE & 4 & 2.187 & 7.289 & 63.930 & 3.81 & .874 \\
\hline 4 & SN & 4 & 4.120 & 13.732 & 39.471 & 3.73 & .910 \\
\hline 5 & FC & 4 & 2.672 & 8.908 & 48.379 & 3.33 & .898 \\
\hline 6 & TPACK & 6 & 7.722 & 25.739 & 25.739 & 3.43 & .943 \\
\hline 7 & IUW & 5 & 2.479 & 8.262 & 56.641 & 3.44 & .925 \\
\hline
\end{tabular}

\section{Main Study}

The main study was conducted after the pilot study. An online survey with Google form was distributed to VHS teachers in three Indonesian provinces, Jambi, Jakarta, and Yogyakarta. The explanation of Web 2.0 technology was included within the sur- 
vey instrument (Appendix). The participants $(n=640)$ age ranged from 20 to more than 50 years old. Besides, their subject area also varied (see Table 3).

Table 2. Participants of the main study

\begin{tabular}{|l|l|c|c|}
\hline \multicolumn{2}{|c|}{$\mathbf{n}=\mathbf{6 4 0}$} & Total & Percentage (\%) \\
\hline \multirow{4}{*}{ Gender } & Male & 265 & 41.4 \\
\hline & Female & 375 & 58.6 \\
\hline \multirow{5}{*}{ Age } & $20-35$ & 324 & 5.63 \\
\cline { 2 - 4 } & $36-50$ & 273 & 42.66 \\
\cline { 2 - 4 } & $>50$ & 43 & 6.72 \\
\hline \multirow{5}{*}{ Subject area } & Maritime & 18 & 2.81 \\
\cline { 2 - 4 } & Creative Industry & 26 & 4.07 \\
\cline { 2 - 4 } & Building technique & 4 & 0.87 \\
\cline { 2 - 4 } & Multimedia & 49 & 7.66 \\
\cline { 2 - 4 } & Business management & 211 & 32.97 \\
\cline { 2 - 4 } & Tourism & 58 & 5 \\
\cline { 2 - 4 } & Agriculture and farming & 105 & 16.41 \\
\cline { 2 - 4 } & Technology engineering & 91 & 14.22 \\
\hline & Others & 78 & 12.19 \\
\hline
\end{tabular}

\section{Results}

Statistical analyses were done using SPSS and AMOS; a two-step SEM [55] was done. A model was examined to establish the convergent validity [56]. We consulted several robust fit indices of CFA in assessing the proposed model; ratio of chi-square to the degrees of freedom $\left(x^{2} / \mathrm{df}\right)<3.0$, Comparative Fit Index $(\mathrm{CFI})>.9$, TuckerLewis Index $(\mathrm{TLI})>.9$, and Root Mean Square Error of Approximation (RMSEA) < .08 [57]. The aim of the CFA was to achieve the acceptable fit indexes of this study. As CFA were not at the desired levels, item dropping and modifications had to be done. Two items, PU4 and WSE4 were dropped while modifications by drawing covariance among error variances were done, e24 to e25. The fit index values for the factors included in this study are as follows: $x^{2}=335$ at $\mathrm{p}<.001$; CFI $=.988$; TLI $=$ .985 ; RMSEA $=.026$. These CFA findings indicate that the index values are acceptable (Fig. 2).

The convergent and divergent validity were also evaluated using the Composite Reliability (CR) and Average Variance Extracted (AVE). Both the CR and AVE are considered to be appropriate when they equal or are greater than $.500[56,58,59,60]$. The AVE value of the factors was from .709 to .916 while the CR ranged from .817 to 936. Factor loadings were also examined for the reliability of the items of each construct. It is appropriate if the standardized loading estimation is greater than .500 [58]. The factor loadings were all above the recommended values. Fig 2 of the CFA indicates that the finalized measurement model of this study is different between all variables. Factor loadings ranged from .58 to .98 . In order to examine the discriminant validity, the square root of the AVE should exceed the inter-factor correlations that are linked with a factor. So that, it can be considered that the factor diverges from 
other factors [56]. Discriminant validity was informed to be satisfactory at the construct level. There were no cross loadings in the current CFA for appropriate results [61].

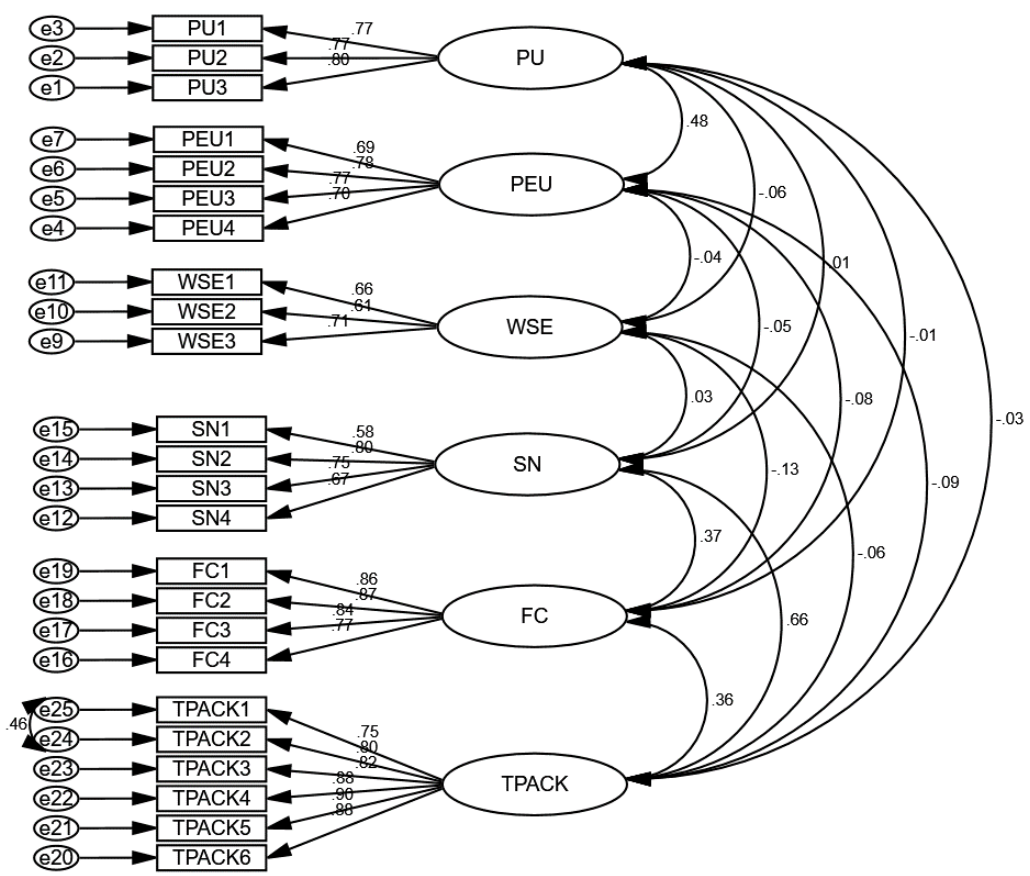

Fig. 2. Confirmatory factor analysis $(n=640)$

\subsection{Key variables for VHS teachers' integration of Web 2.0}

The mean scores and standard deviation for the factors included in this study are summarized in Table 3. Based on the finding, Indonesian VHS teachers' PEU is the highest $(\mathrm{M}=3.92 ; \mathrm{SD}=.553)$ followed by $\mathrm{PU}(\mathrm{M}=3.73$; $\mathrm{SD}=.624)$. They also have a positive perception on $\mathrm{SN}(\mathrm{M}=3.61 ; \mathrm{SD}=.463)$. In addition, their WSE is also high $(\mathrm{M}=3.68, \mathrm{SD}=.368)$. Their TPACK level is higher than $(\mathrm{M}=3.44 ; \mathrm{SD}=.490)$ their perception on FC $(\mathrm{M}=3.35 ; \mathrm{SD}=.596)$. In addition, it was found that the VHS teachers' IUW is also high $(\mathrm{M}=3.60, \mathrm{SD}=.155)$. The reliability of the factors ranged from .700 to .938 . 
Table 3. Descriptive statistics and reliability coefficient (n. 677)

\begin{tabular}{|l|c|c|c|c|}
\hline \multicolumn{1}{|c|}{ Subscale } & Items $(\mathbf{n})$ & M & SD & $\boldsymbol{\alpha}$ \\
\hline PU & 4 & 3.73 & 0.624 & 0.822 \\
\hline PEU & 4 & 3.92 & 0.533 & 0.823 \\
\hline WSE & 4 & 3.68 & 0.368 & 0.7 \\
\hline SN & 4 & 3.61 & 0.463 & 0.917 \\
\hline FC & 4 & 3.35 & 0.594 & 0.901 \\
\hline TPACK & 6 & 3.44 & 0.49 & 0.938 \\
\hline IUW & 5 & 3.5 & 0.155 & 0.919 \\
\hline
\end{tabular}

This study examined whether male and female VHS teachers differed in their approach to IUW in their teaching. The results inform that there is a significant difference $(p>.05)$ between male and female teachers concerning IUW (Table 4). The findings of a one-way ANOVA test of VHS teachers from ages and various subject areas as shown in Table 5 regarding IUW indicate that there are no significant differences based on teachers' ages and subject area $(\mathrm{p}>.05)$.

Table 4. T-test results

\begin{tabular}{|l|c|c|c|c|}
\hline \multicolumn{1}{|c|}{ Gender } & N & M & t-test & p-value \\
\hline Male & 265 & 3.43 & 3.942 & $<.005$ \\
\hline Female & 375 & 3.55 & & \\
\hline
\end{tabular}

Table 5. ANOVA results

\begin{tabular}{|l|c|c|c|c|}
\hline & N & Mean & F & p-value \\
\hline Age & & & & .249 \\
\hline $20-35$ & 324 & 3.51 & 1.395 & \\
\hline $36-50$ & 273 & 3.48 & & \\
\hline$>50$ & 43 & 3.47 & & \\
\hline & & & & \\
\hline Subject area & & & & .992 \\
\hline Building Technique & 4 & 3.47 & & \\
\hline Farming and Agriculture & 105 & 3.49 & & \\
\hline Creative Industry & 26 & 3.50 & & \\
\hline Business management & 211 & 3.48 & & \\
\hline Maritim & 18 & 3.47 & & \\
\hline Multimedia & 49 & 3.47 & & \\
\hline Technologi Engineering & 91 & 3.51 & & \\
\hline Tourism & 58 & 3.48 & & \\
\hline Other & 78 & 3.51 & & \\
\hline
\end{tabular}

\subsection{The relationship between the predicting variables and intention to use Web 2.0 in VHS teaching}

An SEM was established which aimed at investigating to what extent the independent variables predict the dependent variable. Firstly, CFA was conducted for the independent and dependent variables for the SEM (Fig. 3). There were a total of six 
independent variables and one dependent variable. In addition, the fit index values for the final model of this study (Fig. 4 ) are as follows: $x^{2}=331$; CFI $=.979$; TLI $=.984$ and RMSEA $=.045$. When the model is examined, it can be observed that TPACK $(\beta$ $=.52)$, and $\mathrm{SN}(\beta=.25)$ and $\mathrm{FC}(\beta=.07)$ are significant in predicting Indonesian VHS teachers' IUW. Meanwhile, three variables (PU, PEU, and WSE) are not significant in predicting IUW.

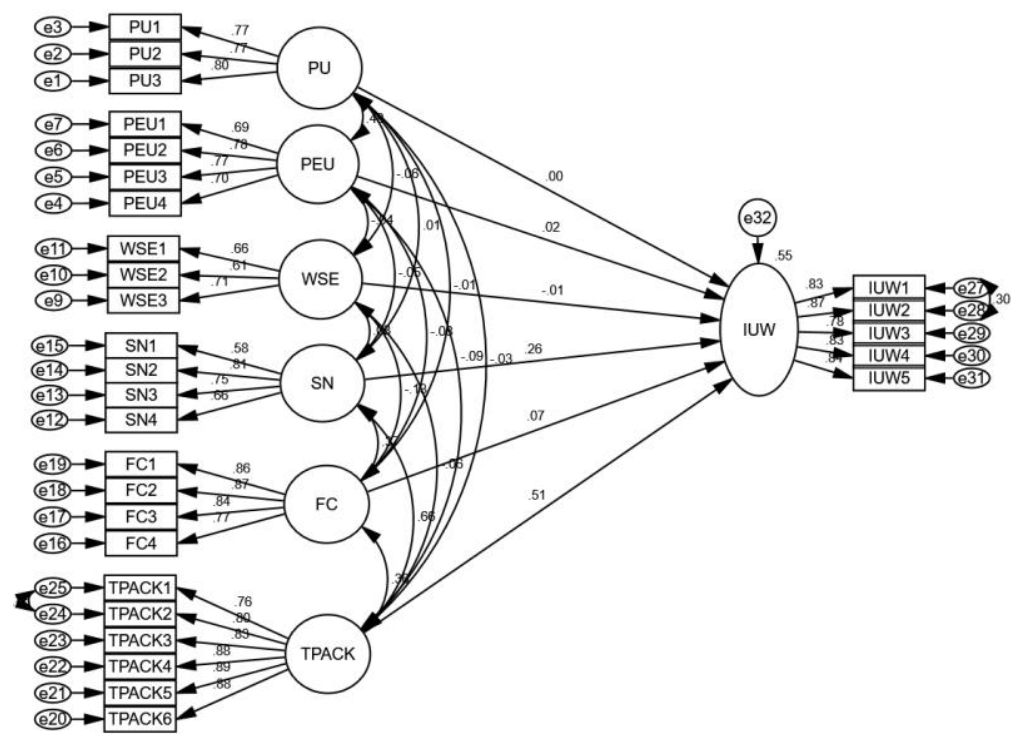

Fig. 3. Path coefficient of the model

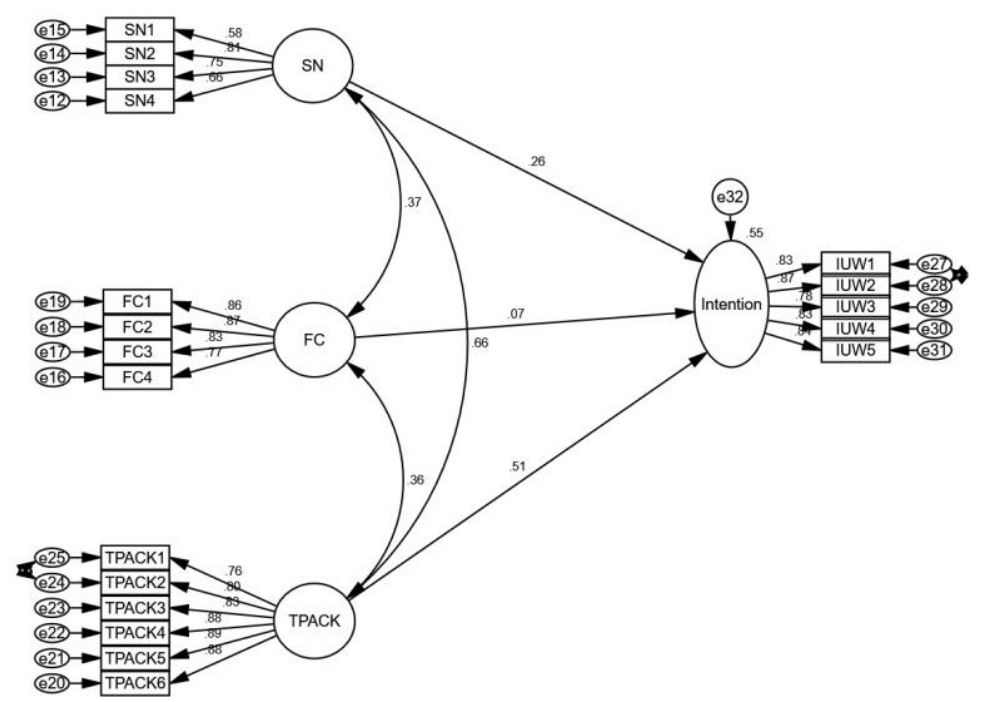

Fig. 4. Final model. 


\section{Discussion}

Firstly, the current study examined whether there are significant differences between gender, age, and subject area regarding Indonesian VHS teachers' IUW. Based on gender, the findings of this study informed that there is a significant difference regarding the participants' IUW. The finding of this study is similar to what [64] reported, that there was a significant difference regarding the use of computer between gender in their study. However, the finding is different to some previous studies which informed that there was no any significant difference between gender regarding the intention or actual use of technology in teaching [45, 62, 63]. This difference might be triggered by the habits of the Indonesian female teachers that were reported to be more discipline and creative in teaching than male teachers [5]. Therefore, the average mean of female participants is higher than those of male participants. In addition, there are no significant differences based on the teachers' age and subject area regarding their IUW. In contrast, some previous studies reported that differences emerged regarding age and subject area [64, 65]. More research on this should be carried out get more understanding on this demographic information.

The main goal of this study was to examine factors influencing Indonesian VHS teachers' IUW in their teaching activity. The main framework applied in this study was TAM [20] supported by TPACK [26] as the extended framework. The results informed that the model is an adequate fit. TPACK, SN, and FC have significant positive influences on IUW. It can be implied that when Web 2.0 is supported with appropriate TPACK, SN, and FC, Indonesian VHS teachers will use Web 2.0 in a greater chance. Three factors were not significant in predicting Indonesian VHS teachers'; IUW; PU, PEU, and WSE.

As a way of thinking about the knowledge, teachers including those who work in vocational education institutions should more understand the effective technology integration into teaching [28]. Web 2.0 facilitates teachers who have well-developed TPACK with new recourses [66]. Our findings show that TPACK influences Indonesian VHS teachers' IUW. It implies that if teachers have a good level of TPACK for Web 2.0 technologies, it will influence the integration in VHS teaching. The level to which teachers perceived that technical infrastructures support the use of technologies in education was also informed to be a predictor of IUW. This finding is similar to prior research conducted in Singapore [67]. SN is also significant in predicting VHS teachers' IUW. For the future use of Web 2.0, SN address the reflection for the VHS teachers' beliefs to their behavior which is influenced, encouraged or discouraged, by their peers, seniors, students, and employers [68].

Unlike motivations such as PU and PEU, PE refers to the pleasure of using Web 2.0 itself. Perceived enjoyment was added [40] to the TAM theory and informed its relationship in influencing intention to use technology. However, our finding does not support this relationship. PE was dropped in the EFA of the pilot test process since it had low reliability or Cronbach's alpha and could not be included in this main study.

For the external motivations, PU does not have significant influences for VHS teachers' IUW. This finding is opposed to what [69] found that PU was a significant predictor for teachers' IUW. PEU is also found to be not significant in predicting In- 
donesian VHS teachers' IUW. Meanwhile, [64] informed that teachers would use technologies once they had beliefs that technologies do not require much effort. In addition, greater technology self-efficacy to use technologies is likely to lead to higher levels of behavioral intention [60]. However, in this study, WSE is not significant in predicting VHS teachers' IUW. This finding might be understood because the high degree of confidence VHS teachers possess for Web 2.0 use in their daily activities.

\section{Conclusion}

The research model for this study is expected to give a contribution to the investigation of the factors influencing VHS teachers' IUW in their teaching for the Indonesian context. In summary, the following factors were identified as the ones that have a strong relationship with VHS teachers' IUW in Indonesia; TPACK, SN and FC. The results of the present study indicate knowledge of technology content and pedagogy influencing of other people in the teachers' cycle and supporting infrastructures play an important role in facilitating Indonesian VHS teachers' IUW in their teaching. This study recommends that government should take an action to improve VHS teachers' TPACK for Web 2.0 integration as well as equip schools with more facilities supporting the teaching with Web 2.0 (e.g. internet, computers, and tablets). The research model benefits future studies to investigate factors influencing Web 2.0 integration into teaching of higher vocational education institutions. The model could also be replicated and applied to in-service teachers for general education, in order to further examine the validation of the results of this study. This article is limited to examine factors influencing Indonesian VHS teachers' IUW in their teaching. It is recommended for future studies to explore more on the actual use of Web 2.0 in VHS teaching. Some approaches such as experimental study and observation are suggested to conduct to get more an in-depth analysis on the actual use of Web 2.0 in education.

\section{$8 \quad$ References}

[1] Anderson, P. (2007). What is Web 2.0? Ideas, technologies and implications for education. Bristol, England: JISC Technology and Standards Watch.

[2] Awang, H., Aji, Z. M., Yaakob, M. F. M., Osman, W. R. S., Mukminin, A., \& Habibi, A. (2018). Teachers' intention to continue using virtual learning environment (VLE): Malaysian context. JOTSE, 8(4), 439-452. https://doi.org/10.3926/jotse.463

[3] Thomas, M., \& Thomas, H. (2012). Using new social media and Web 2.0 technologies in business school teaching and learning. Journal of Management Development, 31(4), 358367. https://doi.org/10.1108/02621711211219013

[4] Mutula, S. M. (2013). E-Government's role in poverty alleviation: case study of South Africa. In Cases on Progressions and Challenges in ICT Utilization for Citizen-Centric Governance (pp. 44-68). IGI Global. https://doi.org/10.4018/978-1-4666-2071-1.ch003

[5] Habibi, A., Mukminin, A., Riyanto, Y., Prasojo, L. D., Sulistiyo, U., Sofwan, M., \& Saudagar, F. (2018). Building an online community: Student teachers' perceptions on the advantages of using social networking services in a teacher education program. Turkish Online Journal of Distance Education, 19(1), 46-61. https://doi.org/10.17718/tojde.382663 
[6] Hoffmann, A. L., Proferes, N., \& Zimmer, M. (2018). "Making the world more open and connected": Mark Zuckerberg and the discursive construction of Facebook and its users. New Media \& Society, 20(1), 199-218. https://doi.org/10.1177/1461444816660784

[7] Ahmad, N., \& Popa, I. L. (2014). The social media usage and the transformation of political marketing and campaigning of the emerging democracy in Indonesia. In Social Media in Politics (pp. 97-125). Springer, Cham. https://doi.org/10.1007/978-3-319-04666-2_7

[8] Muessig, K. E., Nekkanti, M., Bauermeister, J., Bull, S., \& Hightow-Weidman, L. B. (2015). A systematic review of recent smartphone, Internet and Web 2.0 interventions to address the HIV continuum of care. Current HIV/AIDS Reports, 12(1), 173-19. https://doi.org/10.1007/s11904-014-0239-3

[9] Napitupulu, D., Adiyarta, K., Sutabri, T., \& Kamaruddin, K. A. (2018). Analysis of citizen readiness in Indonesia toward e-gov 2.. Journal of Theoretical and Applied Information Technology, 96(19), 6645-6653.

[10] Sayogo, D. S. (2018). Online traceability for halal product information: perceptions of Muslim consumers in Indonesia. Journal of Islamic Marketing, 9(1), 99-116. https://doi. org/10.1108/jima-07-2016-0057

[11] Mukminin, A., Habibi, A., Muhaimin,, Asrial,, Haryanto, E., Setiono, P., \& Sofyan,. (2019). Vocational technical high school teachers' beliefs towards ict for the 21st century education: indonesian context. Problems of Education in the 21st Century, Problems of Education in the 21st Century, 77(1), 22-38. https://doi.org/10.33225/pec/19.77.22

[12] Teo, T., Sang, G., Mei, B., \& Hoi, C. K. W. (2018). Investigating pre-service teachers' acceptance of Web 2.0 technologies in their future teaching: a Chinese perspective. Interactive Learning Environments, 1-17. https://doi.org/10.1080/10494820.2018.148 $\underline{9290}$

[13] Fishbein, M., \& Ajzen, I. (1975). Belief, attitude, intention, and behavior. Reading, MA: Addison-Wesley.

[14] Davis, F. D. (1989). Perceived usefulness, perceived ease of use, and user acceptance of information technology. Mis Quarterly, 13(3), 319-34. https://doi.org/10.2307/249008

[15] Davis, F. D., Bagozzi, R. P., \& Warshaw, P. R. (1989). User acceptance of computer technology: A comparison of two theoretical models. Management Science, 35(8), 982-1003. https://doi.org/10.1287/mnsc.35.8.982

[16] Teo, T. (2011). Technology acceptance research in education. In T. Teo (Ed.), Technology acceptance in education: Research and issues (pp. 1-5). Rotterdam: Sense. https://doi. org/10.1007/978-94-6091-487-4_1

[17] Liaw, S.-S., \& Huang, H.-M. (2003). An investigation of user attitudes toward search engines as an information retrieval tool. Computers in Human Behavior, 19(6), 751-765. https://doi.org/10.1016/s0747-5632(03)00009-8

[18] Taylor, S., \& Todd, P. A. (1995). Understanding information technology usage: A test of competing models. Information Systems Research, 6(2), 144-176. https://doi.org/10.1287/ isre.6.2.144

[19] Ajzen, I. (1991). The theory of planned behavior. Organizational Behavior and Human Decision Processes, 50(2), 179-211. https://doi.org/10.1016/0749-5978(91)90020-t

[20] Davis, F. D. (1993). User acceptance of information technology: System characteristics, user perceptions and behavioral impacts. International Journal of Man-Machine Studies, 38(1), 475-487. https://doi.org/10.1006/imms.1993.1022

[21] Venkatesh, V., \& Davis, F. D. (2000). A theoretical extension of the technology acceptance model: Four longitudinal field studies. Management Science, 46(2), 186-204. https://doi.org/10.1287/mnsc.46.2.186.11926 
[22] Camarero, C., Rodríguez, J., \& San José, R. (2012). An exploratory study of online forums as a collaborative learning tool. Online Information Review, 36(4), 568-586. https:// doi.org/10.1108/14684521211254077

[23] Padilla-Meléndez, A., Garrido-Moreno, A., \& Del Aguila-Obra, A. R. (2008). Factors affecting e-collaboration technology use among management students. Computers \& Education, 51(2), 609-623. https://doi.org/10.1016/j.compedu.2007.06.013

[24] Shroff, R. H., Deneen, C. C., \& Ng, E. M. (2011). Analysis of the technology acceptance model in examining students' behavioural intention to use an e-portfolio system. Australasian Journal of Educational Technology. https://doi.org/10.14742/ajet.940

[25] Teo, T., Milutinović, V., \& Zhou, M. (2016). Modelling Serbian pre-service teachers' attitudes towards computer use: A SEM and MIMIC approach. Computers \& Education, 94, 77-88. https://doi.org/10.1016/j.compedu.2015.10.022

[26] Legris, P., Ingham, J., \& Collerette, P. (2003). Why do people use information technology? A critical review of the technology acceptance model. Information \& Management, 40(3), 191-204. https://doi.org/10.1016/s0378-7206(01)00143-4

[27] Teo, T., \& Zhou, M. (2017). The influence of teachers' conceptions of teaching and learning on their technology acceptance. Interactive Learning Environments, 25(4), 513-527. https://doi.org/10.1080/10494820.2016.1143844

[28] Mishra, P., \& Koehler, M. (2006). Technological pedagogical content knowledge: A framework for teacher knowledge. Teachers College Record, 108(6), 1017-1054. https:// doi.org/10.1111/j.1467-9620.2006.00684.x

[29] Shulman, L. S. (1986). Those who understand: Knowledge growth in teaching. Educational Researcher, 15(2), 4-14. https://doi.org/10.3102/0013189x015002004

[30] Dong, Y., Chai, C. S., Sang, G., Koh, J. H., \& Tsai, C.-C. (2015). Exploring the profiles and interplays of pre-service and inservice teachers' technological pedagogical content knowledge (TPACK) in China. Journal of Educational Technology \& Society, 18(1), 158169.

[31] Archambault, L. M., \& Barnett, J. H. (2010). Revisiting technological pedagogical content knowledge: Exploring the TPACK framework. Computers \& Education, 55(4), 16561662. https://doi.org/10.1016/j.compedu.2010.07.009

[32] Sang, G., Tondeur, J., Chai, C. S., \& Dong, Y. (2016). Validation and profile of Chinese pre-service teachers' technological pedagogical content knowledge scale. Asia-Pacific Journal of Teacher Education, 44(1), 49-65. https://doi.org/10.1080/1359866x.2014.96080 $\underline{0}$

[33] Cox, S., \& Graham, C. R. (2009). Diagramming TPACK in practice: Using an elaborated model of the TPACK framework to analyze and depict teacher knowledge. TechTrends, 53(5), 60-69. https://doi.org/10.1007/s11528-009-0327-1

[34] Montero Perez, M., Peters, E., \& Desmet, P. (2014). Is less more? Effectiveness and perceived usefulness of keyword and full captioned video for L2 listening comprehension. ReCALL, 26(1), 21-43. https://doi.org/10.1017/s0958344013000256

[35] Zacharis, N. Z. (2012). Predicting college students' acceptance of podcasting as a learning tool. Interactive Technology and Smart Education, 9(3), 171-183. https://doi.org/10.11 $\underline{08 / 17415651211258281}$

[36] Ma, Q., \& Liu, L. (2004). The technology acceptance model: A meta-analysis of empirical findings. Journal of Organizational and End User Computing, 16(1), 59-72. https://doi.org/ 10.4018/joeuc.2004010104

[37] Schepers, J., \& Wetzels, M. (2007). A meta-analysis of the technology acceptance model: Investigating subjective norm and moderation effects. Information \& Management, 44(1), 90-103. https://doi.org/10.1016/j.im.2006.10.007 
[38] Saeed, K. A., \& Abdinnour-Helm, S. (2008). Examining the effects of information system characteristics and perceived usefulness on post adoption usage of information systems. Information \& Management, 45(6), 376-386. https://doi.org/10.1016/j.im.2008.06.002

[39] Teo, T., Lee, C. B., \& Chai, C. S. (2008). Understanding pre-service teachers' computer attitudes: Applying and extending the technology acceptance model. Journal of Computer Assisted Learning, 24(2), 128-143. https://doi.org/10.1111/j.1365-2729.2007.00247.x

[40] Davis, F. D., Bagozzi, R. P., \& Warshaw, P. R. (1992). Extrinsic and intrinsic motivation to use computers in the workplace. Journal of Applied Social Psychology, 22(14), 11111132. https://doi.org/10.1111/j.1559-1816.1992.tb00945.x

[41] Bandura, A. (1977). Self-efficacy: Toward a unifying theory of behavioral change. Psychological Review, 84(2), 191-215. https://doi.org/10.1037/0033-295x.84.2.191

[42] Suh, E., Diener, E., Oishi, S., \& Triandis, H. C. (1998). The shifting basis of life satisfaction judgments across cultures: Emotions versus norms. Journal of Personality and Social Psychology, 74(2), 482-493. https://doi.org/10.1037/0022-3514.74.2.482

[43] Aslan, A., \& Zhu, C. (2016). Influencing factors and integration of ICT into teaching practices of pre-service and starting teachers. International Journal of Research in Education and Science, 2(2), 359-37. https://doi.org/10.21890/ijres.81048

[44] Hu, P. J., Chau, P. Y., Sheng, O. R. L., \& Tam, K. Y. (1999). Examining the technology acceptance model using physician acceptance of telemedicine technology. Journal of management information systems, 16(2), 91-112. https://doi.org/10.1080/07421222.1999.1151 $\underline{8247}$

[45] Koh, J. H. L., Chai, C. S., \& Tsai, C. C. (2010). Examining the technological pedagogical content knowledge of Singapore pre-service teachers with a large-scale survey. Journal of Computer Assisted Learning, 26(6), 563-573. https://doi.org/10.1111/j.1365-2729.2010. 00372.x

[46] Sadaf, A., Newby, T. J., \& Ertmer, P. A. (2012). Exploring pre-service teachers' beliefs about using Web 2.0 technologies in K-12 classroom. Computers \& Education, 59(3), $937-$ 945. https://doi.org/10.1016/j.compedu.2012.04.001

[47] Schmidt, D. A., Baran, E., Thompson, A. D., Mishra, P., Koehler, M. J., \& Shin, T. S. (2009). Technological pedagogical content knowledge (TPACK). Journal of Research on Technology in Education, 42(2), 123-149. https://doi.org/10.1080/15391523.2009.107825 $\underline{44}$

[48] Teo, T., \& Beng Lee, C. (2010). Explaining the intention to use technology among student teachers: An application of the Theory of Planned Behavior (TPB). Campus-Wide Information Systems, 27(2), 60-67. https://doi.org/10.1108/10650741011033035

[49] Valtonen, T., Kukkonen, J., Kontkanen, S., Sormunen, K., Dillon, P., \& Sointu, E. (2015). The impact of authentic learning experiences with ICT on pre-service teachers' intentions to use ICT for teaching and learning. Computers \& Education, 81, 49-58. https://doi. org/10.1016/j.compedu.2014.09.008

[50] Muhaimin, M., Habibi, A., Mukminin, A., Saudagar, F., Pratama, R., Wahyuni, S., \& Indrayana, B. (2019). A Sequential Explanatory Investigation of TPACK: Indonesian Science Teachers' Survey and Perspective. Journal of Technology and Science Education, 9(3), 269-281. https://doi.org/10.3926/jotse.662

[51] Yusop, F. D. (2015). A dataset of factors that influence preservice teachers' intentions to use Web 2.0 technologies in future teaching practices. British Journal of Educational Technology, 46(5), 1075-108. https://doi.org/10.1111/bjet.12330

[52] Bartlett, M. S. (1950). Tests of significance in factor analysis. British Journal of statistical psychology, 3(2), 77-85. 
[53] Anderson, J. C., \& Gerbing, D. W. (1988). Structural equation modeling in practice: A review and recommended two-step approach. Psychological Bulletin, 103(3), 411-423. https ://doi.org/10.1037/0033-2909.103.3.411

[54] Fornell, C., \& Larcker, D. F. (1981). Evaluating structural equation models with unobservable variables and measurement error. Journal of Marketing Research, 18(1), 39-5. https:// doi.org/10.2307/3151312

[55] Marsh, H. W., Guo, J., Dicke, T., Parker, P. D., \& Craven, R. G. (2019). Confirmatory Factor Analysis (CFA), Exploratory Structural Equation Modeling (ESEM), and SetESEM: Optimal Balance Between Goodness of Fit and Parsimony. Multivariate behavioral research, 1-18. https://doi.org/10.1080/00273171.2019.1602503

[56] Hair, J. F., Black, W. C., Babin, B. J., Anderson, R. E., \& Tatham, R. L. (2010). Multivariate data analysis: A global perspective (7th ed.). Upper Saddle River, NJ: Pearson Prentice Hall.

[57] Hu, L.-t., \& Bentler, P. M. (1998). Fit indices in covariance structure modeling: Sensitivity to underparameterized model misspecification. Psychological Methods, 3(4), 424-453. https://doi.org/10.1037/1082-989x.3.4.424

[58] Sang, G., Valcke, M., van Braak, J., \& Tondeur, J. (2010). Student teachers' thinking processes and ICT integration: Predictors of prospective teaching behaviors with educational technology. Computers \& Education, 54(1), 103-112. https://doi.org/10.1016/j.compedu. 2009.07.010

[59] Chin, W. W. (2010). How to write up and report PLS analyses. In V. Esposito Vinzi, W. W. Chin, J. Henseler, \& H. Wang (Eds.), Handbook of partial least squares (pp. 655-690). Berlin, Germany: Springer. https://doi.org/10.1007/978-3-540-32827-8_29

[60] Whitley, B. E. (1997). Gender differences in computer-related attitudes and behavior: a meta-analysis. Computer in Human Behavior, 13(1), 1-22. https://doi.org/10.1016/s0747$\underline{\text { 5632(96)00026-X }}$

[61] Pamuk, S. \& Peker, D. (2009). Turkish pre-service science and mathematics teachers' computer related self-efficacies, attitudes, and the relationship between these variables. Computers \& Education, 53(2), 454-461. https://doi.org/10.1016/j.compedu.2009.03.004

[62] Yuen, A. H. K., \& Ma, W. W. K. (2002). Gender differences in teacher computer acceptance. Journal of Technology and Teacher Education, 10(3), 365-382.

[63] Barton, R. \& Haydn, T. (2006). Trainee teachers' views on what helps them to use information and communication technology effectively in their subject teaching. Journal of Computer Assisted Learning, 22(4) 257-272. https://doi.org/10.1111/j.1365-2729.2006.00 $\underline{175 . x}$

[64] Nelson, J., Christopher, A., \& Mims, C. (2009). TPACK and Web 2.0: Transformation of teaching and learning. TechTrends, 53(5), 80-87.

[65] Teo, T. (2009). Modelling technology acceptance in education: A study of pre-service teachers. Computers \& Education, 52(2), 302-312. https://doi.org/10.1016/j.compedu.20 $\underline{08.08 .006}$

[66] Valaei, N., \& Rezaei, S. (2016): Does Web 2.0 utilization leads to knowledge quality, improvisational creativity, compositional creativity, and innovation in small and mediumsized enterprises? A sense-making perspective. Technology Analysis \& Strategic Management, https://doi.org/10.1080/09537325.2016.1213806

[67] Sadaf, A., Newby, T. J., \& Ertmer, P. A. (2016). An investigation of the factors that influence preservice teachers' intentions and integration of Web 2.0 tools. Educational Technology Research and Development, 64(1), 37-64. https://doi.org/10.1007/s11423-015$\underline{9410-9}$ 
Paper-Factors Influencing Intention to Use Web 2.0 in Indonesian Vocational High Schools

\section{Authors}

Lantip Diat Prasojo works at the Universitas Negeri Yogyakarta in Indonesia.

Akhmad Habibi is an associate author works at Universitas Jambi in Indonesia.

Amirul Mukminin, Sofyan, Boy Indrayana \& Kaspul Anwar works for Universitas Jambi in Indonesia.

Article submitted 2019-04-04. Resubmitted 2019-12-08. Final acceptance 2019-12-08. Final version published as submitted by the authors. 


\section{Appendix}

Web 2.0 is the next generation of the world wide web in which it presents a more interactive and dynamic web experience from static HTML pages. The focus of Web 2.0 is on collaboration and sharing functions via social networking services, e.g. Wikis, Blogs, Social Media, Content Hosting Services, and Podcasting.

\subsection{Instrument}

PU, 4

Using Web 2.0 technologies will improve my teaching performance.

Web 2.0 technologies will enhance my teaching effectiveness.

Web 2.0 technologies will increase my productivity in my teaching.

Web 2.0 technologies will be useful for my teaching.

PEU, 4

Learning to use Web 2.0 technologies in teaching will be easy.

Using Web 2.0 technologies in teaching will be clear and understandable.

Using Web 2.0 technologies in teaching will be flexible to interact with.

It will be easy to become skillful at using Web 2.0 technologies in teaching

PE, 4

The process of using Web 2.0 technologies in teaching will be pleasant

Using Web 2.0 technologies in teaching will arouse my curiosity

Using Web 2.0 technologies in teaching will be exciting

I will have fun using Web 2.0 technologies in teaching

WSE, 4

I feel at ease using Web 2.0 technologies.

I know enough to use Web 2.0 technologies.

I am sure of my abilities to use Web 2.0 technologies effectively.

I am confident with my abilities to select appropriate Web 2.0 technologies for teaching.

SN, 4 ing.

People who are important to me support me to use Web 2.0 technologies in teach-

My students will support my use of Web 2.0 technologies in teaching.

Schools support the use of Web 2.0 technologies in teaching.

Policy makers advocate the use of Web 2.0 technologies in teaching.

FC, 4

When I need help to use Web 2.0 technologies in teaching, someone will be there to help me.

When I need help to learn to use Web 2.0 in teaching, someone will be there to teach me.

I will have the resources necessary to teach with the Web 2.0 technologies.

Training for using Web 2.0 technologies in teaching will be available for me.

TPACK, 6 
I can formulate in-depth discussion topics about the content knowledge and facilitate students' online collaboration with appropriate Web 2.0 technologies.

I can design authentic problems about the content knowledge and represent them through Web 2.0 technologies to engage my students

I can structure activities to help students to construct different representations of the content knowledge using appropriate Web 2.0 technologies

I can create self-directed learning activities of the content knowledge with appropriate Web 2.0 technologies.

I can design inquiry activities to guide students to make sense of the content knowledge with appropriate Web 2.0 technologies.

I can design lessons that appropriately integrate content, Web 2.0 technologies, and pedagogy for student-centered learning.

IUW, 5

I will use Web 2.0 technologies in my future teaching.

I plan to use Web 2.0 technologies often in my future teaching.

I intend to use Web 2.0 technologies as much as possible in my future teaching.

I will talk about the positive aspects of using Web 2.0 technologies in my future classroom.

I will recommend Web 2.0 technologies to my future colleagues. 